\title{
Aprendizado e Memória de Trabalho em Camundongos Sob Diferentes Condiçóes de Iluminação - Editorial
}

\author{
Rivelilson Mendes de Freitas \\ Farmacêutico, Doutor em Farmacologia, Docente do Curso de Farmácia da Universidade Federal do Piauí, Teresina-PI, Brasil.
}

Neste número da Revista Neurociências foi publicado o estudo sobre o aprendizado e memória de trabalho em camundongos sob diferentes condições de iluminação ${ }^{1}$. A literatura relata que a aprendizagem pelo desempenho é um processo por meio do qual um padrão motor relativamente estruturado se aperfeiçoa mediante sua própria repetição ${ }^{2}$. O comportamento de camundongos e sua rápida aprendizagem já foram demonstrados em diversos modelos farmacológicos.

Entre esses modelos pode ser citada a caixa de Skinner. Nesse método os animais sáo condicionados a receber alimentos após uma determinada ação ${ }^{3}$. Dessa forma, estudos que investigam as condições ambientais sobre o processo de aprendizagem e memória em roedores são de extrema importância, uma vez que é importante considerar as possíveis consequências sobre comportamento relacionadas com esses processos antes e/ou após as mudanças de parâmetros ambientais.

O referido estudo desta edição enfatizou a importância do conhecimento sobre os efeitos causados pela iluminação ambiental sobre o comportamento animal. Para tanto, foram utilizados camundongos Swiss que exibem comportamento neofílico ${ }^{4,5}$. Estes animais podem ser considerados apropriados para estes estudos que investigam a influência de parâmetros ambientais sobre a cognição. Entretanto, é importante considerar que não há estudos relacionando luminosidade com a aprendizagem e memória de trabalho nestes animais. Desta forma, a hipótese positiva dos autores é demonstrar se as mudanças sobre a iluminação podem prejudicar os processos cognitivos em roedores. $\mathrm{O}$ atual estudo publicado na Revista Neurociências teve como objetivo analisar o efeito de diferentes ciclos claro escuro (CCE) na sala de ambientação, bem como a intensidade da iluminação, durante os testes comportamentais de aprendizagem e memória de trabalho em camundongos suíços. Após um período de habituação na sala correspondente ao alojamento, os camundongos foram divididos em três grupos.

Cada grupo recebeu um conjunto consistente de CCE na sala de habituação (CCE 00:12 h ou luz constante (lux 25) ou completa escuridão). Quatro dias depois, os testes comportamentais foram iniciados. Cada grupo foi subdividido em dois subgrupos de acordo com a intensidade da luz utilizada no momento do teste (lux 500 ou 0). Este procedimento resultou em seis grupos de observação. Os animais de cada tratamento foram testados no labirinto Lashley III para a análise da aprendizagem. Após esse teste comportamental houve uma pausa de dois dias, e os camundongos foram mantidos em sala de habituação com o CCE estabelecido para cada tratamento. Posteriormente, os animais foram submetidos à tarefa de reconhecimento de objetos para avaliar a memória de trabalho.

Após o teste comportamental do labirinto de Lashley III apenas no grupo submetido a completa escuridão e com lux 0 não foi detectada uma redução significativa no número médio de erros. Por outro lado, este parâmetro em todos os tratamentos após o quinto dia foi significativamente menor do que no primeiro dia do teste, sugerindo que houve aprendizagem. Já em relação ao efeito de diferentes condições de CCE na sala de habituação, não houve diferenças estatisticamente significativas entre os tratamentos. Por sua vez, no teste da tarefa de reconhecimento de objeto o mesmo grupo submetido a completa escuridão e com lux 0 náo atingiu um índice de discriminação superior a 0,5 , sugerindo que estes animais não reconheceram adequadamente o objeto, possivelmente porque gastaram mais tempo explorando o mesmo objeto. 
O presente artigo publicado pela Revista de Neurociências é de fundamental importância para os grupos de pesquisa em neuropsicofarmacologia que desenvolvem estudos na área de memória e aprendizagem, uma vez que não há nenhum método que estabeleça quais os parâmetros ambientais que podem prejudicar o desenvolvimento da cognição, plasticidade e memória em humanos, bem como quais destes seriam potencialmente deletérios principalmente sobre o sistema nervoso central de crianças.

Os autores determinaram que apenas em um determinado grupo de animais sobre condiçôes específicas de completa escuridão e lux 0 houve mudanças significativas nos testes comportamentais, estes dados sugerem que estas mudanças induzidas no CCE durante o presente estudo não produzem efeitos sobre as funçóes cognitivas. Além disso, os autores sugerem que a iluminação constante não produz mudanças significativas no desempenho dos animais em testes de aprendizagem e de memória. E que a intensidade da luz durante os testes comportamentais também não demonstram efeito significativo.

Uma das possíveis justificativas para os deficits observados no processo de aprendizagem e memória de trabalho por animais que receberam tratamento de completa escuridáo e lux 0 pode ser devido às baixas concentraçôes de serotonina ${ }^{6}$, por outro lado é sugerido também que animais mantidos em escuridão permanente não tem os parâmetros avaliados influenciados pelos níveis de corticosterona ${ }^{7}$.
Diante destas perspectivas, os resultados do referido trabalho sugerem que a completa escuridão pode prejudicar a aprendizagem e a memória de trabalho em camundongos Swiss, mas os mecanismos moleculares que causam esse efeito ainda não foram completamente esclarecidos e novos estudos precisam ser realizados para mensurar estes e outros parâmetros ambientais sobre a plasticidade sináptica, memória e cognição.

\section{REFERÊNCIAS}

1.Ramos SE, Murgas LDS, Ferreira MR, Mourao-Junior CA. Learning and Working Memory In Mice Under Different Lighting Conditions. Rev Neurocienc 2013;21(3):349-55.

http://dx.doi.org/10.4181/RNC.2013.21.834.7p

2.Andes C, Busch SE. A aprendizagem do descascamento de sementes pelo camundongo Calomys callosus (Rodentia, Cricetidae). Rev Bras Zoociênc 1999;1:31-44.

3.Preis DM, Guzela RR, Roza-Gomes MF. Avaliaçáo da aprendizagem de camundongos da linhagem Balb/c, espécie Mus musculus perante exposição a um novo ambiente em busca de alimento. Unoesc Ciênc ACBS 2011;2:117-22. 4.Bevins RA, Besheer J. Object recognition in rats and mice: a one-trial non-matching-to-sample learning task to study recognition memory. Nat Protoc 2006;1(3):1306-11.

http://dx.doi.org/10.1038/nprot.2006.205

5.Hughes RN. Neotic preferences in laboratory rodents: issues, assessment and substrates. Neurosci Biobehav Rev 2007;31(3):441-64.

http://dx.doi.org/10.1016/j.neubiorev.2006.11.004

6.Arendt J. Melatonin and the pineal gland: influence on mammalian seasonal and circadian physiology. Rev Reprod 1998;3(1):13-22.

http://dx.doi.org/10.1530/ror.0.0030013

7.He WB, Zhang JL, Hu JF, Zhang Y, Machida T, Chen NH. Effects of glucocorticoids on age-related impairments of hippocampal structure and function in mice. Cell Mol Neurobiol 2008;28(2):277-91.

http://dx.doi.org/10.1007/s10571-007-9180-y 